\title{
PENGEMBANGAN INTERVENSI UNTUK TINGKAT PEKERJA DAN TIM KERJA MELALUI GAMES DAN SIMULASI
}

\author{
Umi Fatonah \\ Program Studi Teknologi Pendidikan \\ Fakultas Keguruan dan Ilmu Pendidikan \\ Universitas Ibn Khaldun Bogor \\ Jl. KH. Sholeh Iskandar Km. 2 Kd. Badak, Bogor \\ chruizzy@gmail.com
}

\begin{abstract}
One of the ways used in order to develop people is through training. A training program may include three things, technical training can improve the skills. A lesson can be declared a success if the behavior changes, increased knowledge, and expertise increases. In developing interventions to increase the performance of the employee one of them is through simulations and games. Learning with simulations and games can increase the interest and motivation of the study, because by using the method of simulation and game of student involvement is more dominant, participants can directly interact with learning situations real, besides learning with simulations and games can give you a good understanding of participants, so it can be concluded that the games and simulation is an effective tool in learning and performance interventions employees.
\end{abstract}

Key Words : Performance Intervention, Games and Simulation Method.

\section{PENDAHULUAN}

Pengembangan sumber daya manusia merupakan bagian penting dalam menunjang peningkatan kinerja suatu organisasi. Pengembangan bertujuan untuk meningkatkan efisiensi serta mengembangkan suatu cara sistematis dalam melaksanakan tugas dan kewajiban yang diberikan oleh suatu organisasi. Salah satu cara yang digunakan dalam rangka mengembangkan karyawan adalah melalui pelatihan. Pendidikan dan Pelatihan (Diklat) sebagai upaya dalam mengembangkan sumber daya manusia (SDM) terutama untuk mengembangkan kemampuan intelektual dan kepribadian manusia.

Menurut Henry Simamora (1997) pelatihan (training) adalah proses sistematik pengubahan perilaku para karyawan dalam suatu arah guna meningkatkan tujuan-tujuan organisasional. Dalam pelatihan diciptakan suatu lingkungan dimana para karyawan dapat memperoleh atau mempelajari sikap, kemampuan, keahlian, pengetahuan, dan perilaku 
yang spesifik yang berkaitan dengan pekerjaan.

Seperti yang disebutkan oleh Donald L. Kirkpatrick "Learning can be defined as the extent to which participants change attitude, improve knowledge, and/or increase skill as a result of attending the program" (1998:20). (pembelajaran dapat didefiniskan dimana peserta merubah sikap, meningkatkan pengetahuan, dan / atau meningkatkan keterampilan sebagai hasil dari mengikuti suatu program)

Suatu program pelatihan dapat mencakup 3 hal, yaitu perubahan sikap, meningkatkan pengetahuan dan ketrampilan. Sehingga dapat ditarik kesimpulan bahwa suatu pembelajaran dapat dinyatakan berhasil apabila perilaku berubah, pengetahuan bertambah, dan keahlian meningkat.

Dalam upaya pengembangan intervensi yang dilakukan terhadap peningkatan kinerja karyawan salah satunya yaitu melalui program pelatihan dengan simulasi dan games.

Simulasi yaitu peniruan situasi yang dengan sengaja diadakan untuk mendekati/menyerupai kejadian atau keadaan sebenarnya (Punaji setyosari, 2005).
Pembelajaran dengan simulasi dan games dapat meningkatkan minat dan motivasi peserta yang belajar, karena dengan menggunakan Metode simulasi dan permainan keterlibatan siswa lebih dominan, peserta secara langsung dapat berinteraksi dengan situasi pembelajaran yang sesungguhnya, selain itu pembelajaran dengan simulasi dan game dapat memberikan pemahaman yang baik terhadap peserta, sehingga dapat disimpulkan bahwa permainan dan simulasi adalah alat yang efektif dalam pembelajaran dan intervensi kinerja karyawan.

\section{PEMBAHASAN}

\section{A. Pengetahuan dan Kompetensi Kerja \\ Dalam dunia kerja kompetensi} didefinisikan sebagai aspek yang penting dan menentukan performansi pekerja. Sebagian besar dari pekerja akan menghasilkan performansi yang efektif jika mereka memiliki pengetahuan, ketrampilan serta perilaku (knowledge, skill, and attitude) yang cukup baik dan dapat diaplikasikan secara bersamaan. Berbagai tipe kompetensi kerja dapat dinyatakan dan dikelompokkan dalam 2 kategori, yaitu kompetensi tekhnikal dan kompetensi perilaku 
(Tjakraatmadja dan Lantu, Knowledge Management dalam Konteks Organisasi Pembelajar, 2006).

\section{1). Kompetensi Teknikal}

Adalah tipe kompetensi yang diekspresikan dalam ketrampilan kerja (hard skill). Ketrampilan teknikal seseorang tergambar dari kemampuannya untuk menyelesaikan tugas-tugas utamanya,atau kompetensi yang berkaitan dengan pekerjaan untuk menghasilkan kinerja yang terbaik atau kemampuannya dalam memahami detail dari suatu pekerjaan.

\section{2). Kompetensi Perilaku}

Adalah tipe kompetensi yang di ekspresikan dalam perilaku seseorang saat bekerja, atau sering juga disebut soft skill. Misalnya peduli terhadap pelayanan pelanggan adalah salah satu jenis dari kompetensi perilaku, dimana seorang pekerja harus memutuskan tentang bagaimana ia harus bersikap ketika menghadapi pelanggan.

\section{B. Mengembangkan Pengetahuan dan Ketrampilan kerja Karyawan}

Seluruh karyawan mulai dari operator sampai posisi pimpinan, memiliki komitmen untuk menghasilkan produk dengan kualitas prima, dimana prestasi pimpinan organisasi diukur oleh kemampuannya mencapai suatu target yang berkualitas.

Oleh sebab itu pimpinan organisasi harus mampu memberikan pendidikan dan pelatihan yang sistematik untuk menghasilkan pengetahuan dan ketrampilan yang dibutuhkan oleh system kerja yang baru. Pendidikan dan pelatihan sebaiknya diarahkan untuk meningkatkan kompetensi untuk memodelkan, menganalisis, dan merancang kembali proses kerja yang ada.

Pelatihan mempunyai andil besar dalam menentukan efektivitas dan efisiensi organisasi. Beberapa manfaat nyata dari program pelatihan dan pengembangan adalah :

1) Meningkatkan kuantitas dan kualitas produktivitas.

2) Mengurangi waktu belajar yang diperlukan karyawan agar mencapai standard kinerja yang diterima.

3) Menciptakan sikap, loyalitas, dan kerjasama yang lebih menguntungkan. 
4) Memenuhi kebutuhan-kebutuhan sebagai bagian dari pengalaman perencanaan sumber daya pelatihan. Minat dan motivasi manusia.

partisipan biasanya tinggi dalam

5) Mengurangi jumlah dan biaya latihan-latihan simulasi karena kecelakaan kerja.

tindakan-tindakan yang diambil sangat

6) Membantu karyawan dalam

menyerupai kondisi pekerjaan

peningkatan dan pengembangan

sesungguhnya. Simulasi sangat pribadi mereka.

Program pelatihan yang efektif berfaedah apabila pelatihan pada pekerjaan dapat mengakibatkan adalah bantuan yang penting dalam perencanaan karir dan sering dipandang sebagai penyembuh penykit-penyakit organisasional. kecelakaan serius, kesalahan yang mahal, atau kerusakan bahan-bahan yang sangat berharga.

Apabila produktivitas anjlok, pada saat

Salah satu kelebihan simulasi dan game adalah pembelajaran ketidakhadiran dan perputaran menyenangkan dan menghibur karyawan tinggi dan juga manakala kalangan karyawan menyatakan ketidakpuasannya, maka solusinya adalah program pelatihan diseluruh perusahaan.

sehingga dengan metode ini mampu menjadi motivasi bagi peserta yang dapat digunakan pelatih untuk meningkatkan keterlibatan dan fokus pada topik yang diajarkan.

Hal ini sesuai dengan pendapat

\section{Simulasi dan Games}

James A Persing dalam bukunya

Simulasi mengacu kepada materimateri yang berupaya menciptakan suatu lingkungan pengambilan keputusan yang realistic bagi petatar. Teknik simulasi memungkinkan seorang individu mengalami interaksi diantara bidang-bidang fungsional didalam organisasi, antara organisasi dengan kompetitornya, atau antara organisasi dengan lingkungannya Human Performance Technology yang menyatakan bahwa Games may achieve many desired outcomes, such as:

1) Increased skill

2) Understanding the implementation of a process

3) Deeper understanding of relationships and concepts

4) Awareness of cross-training needs 
Penggunaan game dapat Perusahaan memiliki standar dan meningkatkan ketrampilan, peserta kebijakan internal terkait lebih mudah memahami proses pengoperasian kendaraan ringan yang pelaksanaan, sehingga akan aman dan selamat. Tujuan dari standar meningkatkan pemahaman peserta dan kebijakan ini untuk memastikan terhadap materi.

Tujuan utama pembelajaran dengan game adalah pembelajaran yang menyenangkan. Sedangkan simulasi lebih ke bagaimana pengalaman yang didapat dari proses belajar melalui simulasi.

\section{STUDY KASUS}

Berikut ini adalah contoh intervensi yang menggunakan berbagai permainan dan simulasi yang ada di departemen pelatihan PT Freeport Indonesia.

PT Freeport Indonesia berkeyakinan bahwa karyawan adalah asset yang berharga diperusahaan. Perusahaan berkeyakinan bahwa semua insiden K3 dapat dicegah. PT Freeport Indonesia memiliki area kerja yang luas dari dataran tinggi (Highland) sampai dataran rendah (Low Land). Kendaraan Ringan (Light Vehicle) Toyota Land Cruiser adalah salah satu alat kerja yang dipakai untuk mendukung kegiatan operasi penambangan. pengopersian yang benar dan aman terkait pengoperasian kendaraan ringan di area kerja perusahaan.

Meskipun perusahaan memliki standard dan kebijakan internal tetapi jumlah angka insiden pengoperasian kendaraan ringan tetap tinggi dan menjadi perhatian khusus. Terdapat 486 insiden kendaraan ringan ditahun 2013 dan sebagian besar penyebab langsungnya adalah Gagal Mengikuti Prosedur dengan total biaya yang timbul sekitar U\$567,081 (sekitar Rp. 7,3 milyar) dan total biaya insiden ditahun 2014 sekitar U\$300,925 (sekitar Rp. 3,9 milyar).

\section{A. Kondisi Saat ini}

Departemen pelatihan menerima banyak permintaan untuk program, pelatihan terkait pengoperasian kendaraan ringan. Terdapat 150 list antrian. Program penyegaran berdasarkan lisensi area, saat ini program yang diberikan belum seluruhnya sama dikarenakan beberapa hal, tidak ada Alur Proses dan 
kurangnya ketersediaan tenaga pengajar. Beberapa pengawas menganggap bahwa salah satu penyebab insiden dikarekan kurang baiknya program pelatihan meskipun hasil investigasi tidak menyebutkan demikian.

Didalam dunia industry, kompetensi didefinisikan sebagai aspek yang penting dalam menentukan kinerja karyawan. Sebagian besar karyawan dapat mendemonstrasikan kinerja yang efektif apabila mereka memiliki pengetahuan, keahlian dan sikap yang memenuh standard dan diterapkan secara bersama-sama.

PT Freeport Indonesia menerapkan sistem kompetensi sebagai berikut:

Skills + Knowledge + Attitude $=$ Competence

Untuk memastikan hal diatas terkadi, ada 4 hal yang diperlukan (Donald L. Kirkpatrick, Evaluating training program, 1998:21)

1) Orang harus berkinginan untuk berubah

2) Orang harus tau apa yang harus dilakukan dan bagaimana melakukanya

3) Orang harus melakukannya dengan benar
4) Orang harus dihargai atas usahanya dalam melakukan perubahan

Program pelatihan membantu bagian pertama dan kedua dengan cara membuat perilaku yang positif dengan mengajarkan pengetahuan dan keahlian yang diperlukan. Kondisi ketiga mengacu kepada atasan langsung karyawan, sedangkan bagian keempat dipengaruhi kondisi intrinsic atau extrinsic.

Departemen pelatihan terus berupaya untuk memperbaiki program pelatihan, yaitu melalui penggunaan Simulator dan game untuk mendukung kegiatan pelatihan, lisensi dan penyegaran.

\section{B. Simulator \& game}

Beberapa keuntungan sebagai berikut:

1) Tidak ada biaya bahan bakar.

2) Meniadakan biaya kerusakan alat selama proses pelatihan.

3) Biaya pengoperasian yang lebih murah dibandingkan dengan menggunakan alat yang sesunguhnya, biaya bahan bakar dan lainnnya.

4) Dapat dioperasikan 24 jam/ hari.

5) Kondisi yang lebih aman. 
6) Meniadakan cedera-cedara James A Persing. (2006). Handbook of operator. Human Performance Technology.

7) Dapat dibuat konfiguarsi kondisi USA. Pfeiffer. darurat yang tidak dapat dilakukan apabila menggunakan alat sesungguhnya: rem blong, jalan yang selip, bahaya api.

8) Dapat dipergunakan untuk pelatihan, pengujian dan refresher.

\section{DAFTAR PUSTAKA}

Henry Simamora. (1997). Manajemen Sumber Daya Manusia. Yogyakarta. STIE YKPN.

Donald L. Kirkpatrick.(1998). Evaluating Training Programs The Four Levels. San Francisco. Berrett-Koehler Publisher, Inc.

Jann Hidajat Tjakraatmadja. Donald Crestofel Lantu. (2006). Knowledge Management dalam Konteks Orgnisasi Pembelajar. Bandung. SBMITB Bandung.

David c Gibson, Gerald Knezek, Pamela Redmond, Elizabeth Bradley. (2014) Handbook of Game and Simulation in Teacher Education. USA. AACE. 